\title{
Terminal elektrowni gazowej ujęty w koncepcji budowy Portu Zewnętrznego w Gdyni a bezpieczeństwo energetyczne Rzeczypospolitej Polskiej
}

\author{
The gas plant terminal included \\ in the concept of the Gdynia External Seaport construction \\ and the energetic security of the Republic of Poland
}

This article analyses the possibilities of increasing natural gas supplies by sea and electricity production based on the construction of a gas plant terminal as part of the investment plans of Port of Gdynia Authority related to the construction of the External Seaport. The issue is considered in a broad political and economic context including the functional aspects of the gas plant terminal. Finally, the author estimates the surplus energy and natural gas which could be delivered to the national power system and other recipients.

Keywords: seaport, gas plant terminal, LNG, energetic security, External Seaport, Gdynia

Słowa kluczowe: port morski, terminal elektrowni gazowej, LNG, bezpieczeństwo energetyczne, Port Zewnętrzny, Gdynia

\section{Wstęp}

Artykuł stanowi sprawozdanie z części analiz dokonanych w Akademii Marynarki Wojennej w ramach pracy badawczej na temat „Bezpieczeństwo dostaw surowców o znaczeniu strategicznym dla bezpieczeństwa energetycznego Rzeczypospolitej Polskiej (RP) realizowanych drogą morską".

Problem główny niniejszego opracowania zawiera się w pytaniu: W jaki sposób realizacja koncepcji budowy terminala elektrowni gazowej w Porcie Zewnętrznym w Gdyni może się przyczynić do zwiększenia dostaw gazu 
ziemnego drogą morską oraz produkcji energii elektrycznej na potrzeby odbiorców w kraju?

Rozwiązaniu problemu głównego posłużyło wyodrębnienie następujących problemów szczegółowych:

- Jaki jest gospodarczy i polityczny kontekst dostaw surowców o znaczeniu strategicznym dla bezpieczeństwa energetycznego RP realizowanych drogą morską?

- Jakie są zamierzenia inwestycyjne Zarządu Morskiego Portu Gdynia (ZMPG) w związku z budową Portu Zewnętrznego?

- W jaki sposób planowany terminal elektrowni gazowej może się przyczynić do zwiększenia bezpieczeństwa energetycznego kraju?

Wobec powyższego celem głównym niniejszej publikacji jest analiza potrzeby i możliwości zwiększenia dostaw gazu ziemnego drogą morską oraz produkcji energii elektrycznej w oparciu o budowę terminala elektrowni gazowej w ramach realizacji zamierzeń inwestycyjnych ZMPG związanych $\mathrm{z}$ budową Portu Zewnętrznego.

Operacjonalizacja celu głównego wymagała określenia następujących celów szczegółowych:

- rozważenie szerokiego kontekstu gospodarczego i politycznego analizowanego zamierzenia,

- zaprezentowanie podstaw i aktualnej koncepcji budowy Portu Zewnętrznego w Gdyni,

- szczegółowa analiza zasadniczych elementów funkcjonalnych terminala elektrowni gazowej pod kątem ich wpływu na bezpieczeństwo energetyczne Polski.

Charakter prowadzonych badań oraz sposób sformułowania analizowanego problemu pozwalają na odstąpienie od przypuszczeń wyrażonych w hipotezach ${ }^{1}$.

Podstawową metodą badawczą służącą realizacji celu artykułu jest krytyczna analiza literatury przedmiotu, koncepcji realizacyjnej, materiałów konferencyjnych i prasy specjalistycznej, uwzględniająca doświadczenie autora zdobyte w trakcie kilkunastu lat pracy zawodowej na pokładach jednostek pływających, m.in. o złożonych układach energetyczno-napędowych dużych mocy.

Układ artykułu odzwierciedla przyjęte założenia i cele badawcze. Tekst składa się z części wstępnej, rozdziałów merytorycznych, które odpowiadają zakresem sformułowanym powyżej celom szczegółowym, oraz części

1 J. Apanowicz, Metodologia ogólna, Bernardinum, Gdynia 2002, s. 44-51. 
końcowej, gdzie zawarto podsumowanie i wskazano możliwe kierunki dalszych badań w tym obszarze.

W przyjętym aparacie pojęciowym port morski stanowi węzłowy punkt transportowy usytuowany na styku dwóch środowisk naturalnych, technicznie i organizacyjnie przygotowany do obsługi różnych morskich i lądowych środków transportowych zaangażowanych w przewozy masy ładunkowej w obrocie krajowym i międzynarodowym, a także pasażerów ${ }^{2}$. Współczesny port morski jest rozległym obszarowo i przestrzennie rynkowym podmiotem gospodarczym, na terenie którego funkcjonuje wiele różnych przedsiębiorstw i firm świadczących określone usługi portowe, głównie logistyczne na rzecz statków i towarów, które weszły do danego portu. Jak każdy podmiot rynkowy, port morski musi mieć osobowość prawną, odpowiednią strukturę organizacyjno-funkcjonalną, stosowne do zadań wyposażenie i uzbrojenie techniczno-technologiczne oraz wydajny system kierowania i zarządzania całym przedsięwzięciem portowym funkcjonującym w wymiarze międzynarodo$w{ }^{3}$. Sprawność obiektów i urządzeń infrastrukturalnych portu zasadniczo podnoszona jest przez urządzenia suprastruktury portowej, które pełnią funkcje pomocnicze i usługowe wobec zasadniczych elementów infrastrukturalnych ${ }^{4}$. Pod kątem funkcjonalnym, służącym realizacji określonych procesów w porcie morskim, jego infrastruktura i suprastruktura łączą się w terminale, np. pasażerskie, kontenerowe, promowe, LNG, paliw płynnych, masowe itd. Wobec powyższego infrastruktura i suprastruktura portowa służąca jednocześnie przyjęciu i rozładowaniu zbiornikowców LNG (pirs rozładunkowy), magazynowaniu dostawy (zbiorniki) oraz produkowaniu w oparciu o nią energii elektrycznej (elektrownia gazowa) określana jest mianem terminala elektrowni gazowej, co zresztą zostało odzwierciedlone w Koncepcji realizacyjnej „,Budowa Portu Zewnętrznego w Porcie Gdynia”.

\section{Kontekst gospodarczy i polityczny}

„Współczesne środowisko bezpieczeństwa międzynarodowego jest coraz bardziej niepewne i złożone. Dzieje się tak wskutek nieustannego poszerzania się sieci globalnych połączeń politycznych, militarnych, gospodarczych i społecznych, co wywiera bezpośredni wpływ na relacje między państwami,

2 W. Rydzkowski, K. Wojewódzka-Król, Transport. Aktualne problemy integracji z UE, Wydawnictwo Naukowe PWN, Warszawa 2008, s. 183.

3 K. Ficon, Logistyka morska - statki, porty, spedycja, BEL Studio, Warszawa 2010, s. 186.

4 Tamże, s. 193. 
podmiotami pozapaństwowymi i poszczególnymi ludźmi. Pojawiają się nowe zagrożenia dla bezpieczeństwa, które wymagają skutecznego, adekwatnego do nowych wyzwań przeciwdziałania ze strony władz państwa. Nadmorskie położenie Polski ma strategiczne znaczenie dla bezpieczeństwa narodowego oraz społeczno-gospodarczego rozwoju, z wszelkimi wynikającymi z tego konsekwencjami"s.

W związku z powyższym szczególnego znaczenia nabiera również problematyka dostarczania drogą morską surowców o znaczeniu strategicznym dla bezpieczeństwa energetycznego RP.

Po pierwsze, Polska jest krajem zależnym od zewnętrznych dostaw gazu ziemnego i ropy naftowej. Pozyskiwanie energii pierwotnej w kraju sukcesywnie zmniejsza się - na przykład w 2017 r. odnotowało spadek o 2,9 proc. w stosunku do roku poprzedniego i wyniosło 2723,7 PJ (petadżul - bilion kilodżuli) ${ }^{6}$. Spadek dotyczył węgla kamiennego, gazu ziemnego i ropy naftowej, natomiast w przypadku węgla brunatnego i pozostałych nośników energii nastąpiło nieznaczne zwiększenie pozyskania ${ }^{7}$.

Po drugie, wraz ze wzrostem gospodarczym i dynamicznym rozwojem kraju zwiększa się zapotrzebowanie na energię elektryczną. W $2017 \mathrm{r}$. PKB w cenach bieżących wyniósł w Polsce $1982080 \mathrm{mln}$ zł, a jego dynamika w porównaniu roku 2017 do 2010 (w cenach stałych) wynosi 125 proc. Proporcjonalnie wzrasta zużycie energii pierwotnej, które np. w 2016 r. wyniosło 94,3 Mtoe (ang. million tonnes of oil equivalent - milion ton ekwiwalentu ropy $)^{8}$.

Po trzecie, polski potencjał energetyczny, który w zasadniczym stopniu opiera się na produkcji energii z węgla, odprowadza do powietrza atmosferycznego ogromne ilości dwutlenku węgla. W 2017 r. globalna emisja tego gazu wyniosła ponad 36 mld ton, z czego Polska wyemitowała aż $326,6 \mathrm{mln}$ ton, co w skali świata daje 0,9 proc. ${ }^{9}$ Mimo że ogólnie produkcja energii

5 A. Duda, Stowo wstepne, [w:] Strategiczna koncepcja bezpieczeństwa morskiego Rzeczypospolitej Polskiej, Biuro Bezpieczeństwa Narodowego, Warszawa-Gdynia 2017.

6 Najważniejszym pod względem wielkości wydobycia nośnikiem energii był w $2017 \mathrm{r}$. węgiel kamienny (57,9 proc.), a drugim - węgiel brunatny (18,7 proc.). Na kolejnych miejscach znajdowały się gaz ziemny $(5,3$ proc.), ropa naftowa $(1,5$ proc.) i pozostałe, w znacznej mierze energia odnawialna (łącznie 16,6 proc.).

7 Gospodarka paliwowo-energetyczna w latach 2016 i $2017=$ Energy statistics in 2016 and 2017, Główny Urząd Statystyczny, Warszawa 2018, s. 15.

8 Energia 2018 = Energy 2018, Główny Urząd Statystyczny, Warszawa 2018, s. 3.

9 Polska pod względem emisji dwutlenku węgla znajduje się na niechlubnym dwudziestym pierwszym miejscu na świecie, jednak zaznaczmy dla porównania, że udział Chin, które zajmują tu miejsce pierwsze, wynosi 27 proc., USA - 15 proc., a Indii - 7 proc. 
ze wszystkich paliw kopalnych generuje ok. 70 proc. światowej emisji gazów cieplarnianych, to szkodliwość każdego z nich jest różna ${ }^{10}$. W tym kontekście zmniejszanie udziału węgla na rzecz gazu ziemnego w produkcji energii jest zadaniem uzasadnionym, zwłaszcza że w świetle uzgodnień poczynionych w trakcie Konferencji Narodów Zjednoczonych w sprawie Zmian Klimatu (powszechnie znanej jako szczyt klimatyczny), która odbyła się w dniach 2-14 grudnia 2018 r. w Katowicach, zostaliśmy niejako zobligowani do niezwłocznego podjęcia skutecznych działań.

Po czwarte, dywersyfikacja kierunków i źródeł dopływu surowców energetycznych do Polski może się przyczynić do poprawy pozycji negocjacyjnej państwa przed wygaśnięciem w 2022 r. umów na dostawy gazu z Federacji Rosyjskiej.

\section{Port Zewnętrzny w Gdyni}

Pierwsze, niemal hasłowe wzmianki prasowe i medialne dotyczące koncepcji budowy Portu Zewnętrznego w Gdyni pochodzą z drugiej połowy $2017 \mathrm{r}$. Wzbudzały one ogromne zainteresowanie, ale również pewien niepokój, związany z zakresem i charakterem ewentualnej inwestycji. Doskonałą okazją do oficjalnego zaprezentowania szerokiemu gronu interesariuszy nowego pomysłu na rozwój Portu Gdynia było XVII Forum Gospodarki Morskiej zorganizowane 13 października 2017 r. w gdyńskim Centrum Konferencyjnym Pomorskiego Parku Naukowo-Technologicznego. Zamierzenia inwestycyjne ZMPG znakomicie korespondowały z tematem przewodnim forum, którym były perspektywy gospodarki morskiej w Polsce w świetle najnowszych trendów na rynkach światowych ${ }^{11}$. Dyrektor naczelny i prezes zarządu ZMPG Adam Meller stwierdził, że „Port Gdynia stoi przed wielką szansą odbudowy znaczenia i stworzenia przewagi nad konkurencją wśród portów Morza Bałtyckiego, a pomysł budowy Portu Zewnętrznego spotkał się z pozytywnym oddźwiękiem oraz wielkim zainteresowaniem wśród [...] potencjalnych inwestorów ${ }^{12}$ ".

10 Global carbon budget 2017, Copernicus Publications, 2018, s. 426.

11 Forum Gospodarki Morskiej Gdynia 2017, „Centrum Prasowe PAP” [online], 21 VI 2017 [dostęp: 15 III 2019], dostępny w internecie: <http://centrumprasowe.pap.pl/cp/pl/ news/info/100567,1,forum-gospodarki-morskiej-gdynia-2017>.

12 Port Zewnętrzny na Forum Gospodarki Morskiej, „Gospodarka Morska” [online], 12 X 2017 [dostęp: 18 III 2019], dostępny w internecie: <https://www.gospodarkamorska.pl/ Porty,Transport/port-zewnetrzny-na-forum-gospodarki-morskiej.html $>$. 
Rok później, 18 października 2018 r. zorganizowano konferencję, której przedmiotem była budowa Portu Zewnętrznego w Gdyni. Uczestniczący w niej minister gospodarki morskiej i żeglugi śródlądowej Marek Gróbarczyk powiedział, że „Port Zewnętrzny wyniesie Gdynię na zupełnie inną półkę i pozwoli konkurować z innymi nadmorskimi miastami na świecie ${ }^{13}$ ". Podkreślił też, że planowany projekt inwestycyjny jest zarówno kluczowy dla rozwoju Gdyni, jak i strategiczny z punktu widzenia interesów Polski.

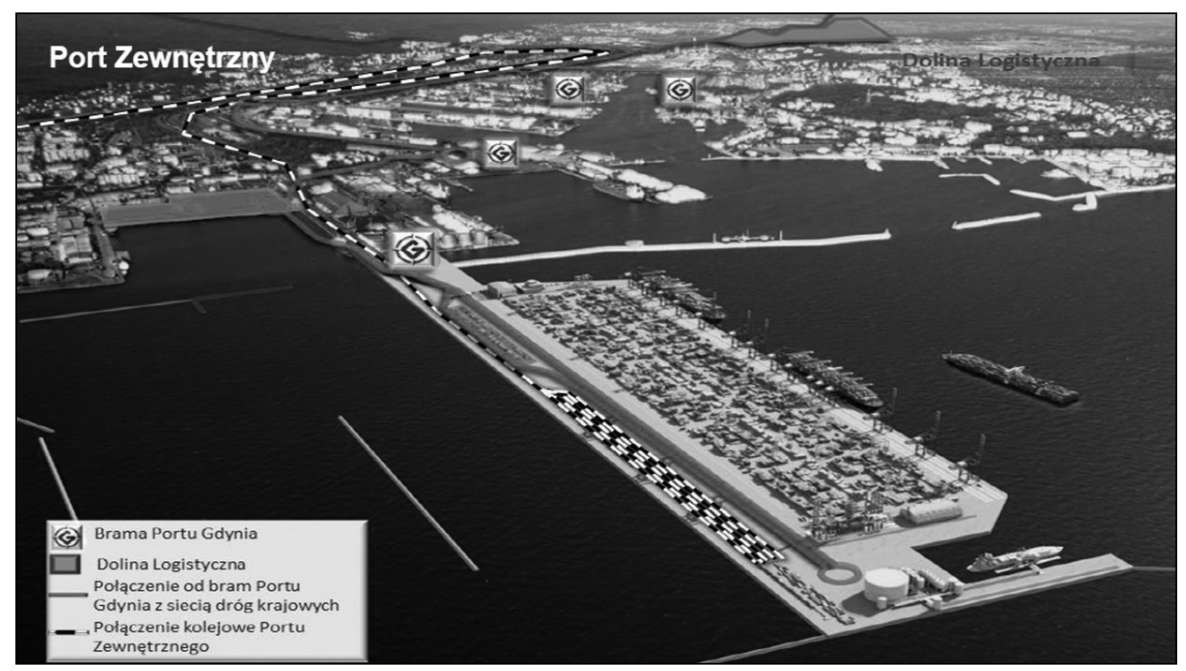

Ryc. 1. Planowane połączenia drogowe i kolejowe Portu Zewnętrznego.

Źródło: Prezentacja konferencyjna Port Zewnętrzny, Port Gdynia, Gdynia 2019, [s. 11], dostępna w internecie [dostęp: $20 \mathrm{XI}$ 2019]: <https://oficynamorska.pl/wp-content/ uploads/2018/10/Konf.-prasowa-2018-10-17m.pdf>

W wywiadzie opublikowanym 13 grudnia 2018 r. na łamach „Dziennika Bałtyckiego" prezes ZMPG dokonał podsumowania mijającego roku, zaprezentował bieżące inwestycje w porcie i dalsze plany rozwojowe. Przyjęta przez ZMPG strategia rozwoju pozwala na coroczny wzrost realizowanych $\mathrm{w}$ porcie przeładunków. W 2018 r. odnotowano rekordowy wolumen $23 \mathrm{mln}$ ton, który wynika m.in. z wysokiej dynamiki na globalnym rynku transportu morskiego oraz dobrego stanu gospodarki narodowej. Konsekwencją tej koniunktury

13 S. Szadurski, Budowa Portu Zewnętrznego w Gdyni. Trwaja poszukiwania inwestora, który pomoże sfinansować przedsięwzięcie, „Dziennik Battycki” [online], $18 \mathrm{X}$ 2018 [dostęp: 24 III 2019], dostępny w internecie: <https://dziennikbaltycki.pl/ budowa-portu-zewnetrznego-w-gdyni-trwaja-poszukiwania-inwestora-ktory-pomozesfinansowac-przedsiewziecie-zdjecia-wizualizacja/ar/13597584>. 
muszą być i są projekty inwestycyjno-modernizacyjne właściwie bilansujące poniesione koszty z zyskami dla spółki i całego kraju. Prezes podkreśla jednak, że utrzymanie tego systematycznego wzrostu jest ściśle powiązane z integracją portu z zapleczem gospodarczym kraju poprzez wydajną infrastrukturę kolejową i drogową (ryc. 1). Działaniom tym przyświeca cel określony w wytycznych polityki transportowej Unii Europejskiej, tj. obsługiwanie do $2030 \mathrm{r}$. ponad 35 proc. ładunków drogą kolejową. Uwzględniając fakt, że Port Gdynia stanowi początek kluczowego dla Unii Europejskiej korytarza transportowego między Bałtykiem i Adriatykiem, realizacja tego celu jest nie tylko możliwa, ale wręcz konieczna, gdyż wynika z przyjętych zobowiązań ${ }^{14}$.

Dyrektor Meller podkreśla ponadto, że „Port Zewnętrzny to obecnie najważniejszy element rozwoju portu i inwestycja o wielkim znaczeniu dla całej polskiej gospodarki morskiej”, a jednocześnie zaznacza, że „,nowa inwestycja pozwoli wzmocnić potencjał przeładunkowy i będzie mocnym atutem w konkurowaniu Portu Gdynia z portami basenu Morza Północnego i Adriatyckiego"15.

Planowany w ramach programu Port Gdynia 2030 głębokowodny Port Zewnętrzny ma powstać na wodach Zatoki Gdańskiej ${ }^{16}$. Będzie funkcjonował w oparciu o nabrzeże o długości 2500 i szerokości $700 \mathrm{~m}$, dobudowane na zatoce w kierunku wschodnim od obecnie istniejącej infrastruktury i suprastruktury portowej. Centralną część Portu Zewnętrznego stanowić ma terminal kontenerowy, umożliwiający przeładunek $2 \mathrm{mln} \mathrm{TEU}^{17}$. Ten podstawowy wariant może jednak ulec zwiększeniu, ponieważ w przygotowanym projekcie przewidziano rezerwę terenu umożliwiającą przeładunek kolejnych $0,5 \mathrm{mln}$ TEU. Terminal ma zapewnić możliwość obsługi kontenerowców o maksymalnej wielkości 30 tys. TEU. Rzecz jasna, w koncepcji budowy Portu Zewnętrznego uwzględnione zostały również inne jego funkcje, takie jak terminal uniwersalny, terminal $\mathrm{LNG}^{18}$ oraz terminal do przeładunku paliw płynnych.

14 Pracowity rok 2018 Portu Gdynia. Cel główny-Port Zewnętrzny, „Port Gdynia” [online], 13 XII 2018 [dostęp: 26 III 2019], dostępny w internecie: <https://www.port.gdynia.pl/ pl/wydarzenia/aktualnosci/1305-pracowity-rok-2018-portu-gdynia-cel-glowny-portzewnetrzny>.

15 Wypowiedź Adama Mellera podczas konferencji pt. „Zamierzenia inwestycyjne Zarządu Morskiego Portu Gdynia S.A. w zakresie budowy Portu Zewnętrznego a działalność Marynarki Wojennej” zorganizowanej 4 IV 2019 r. w Akademii Marynarki Wojennej.

16 Coraz bliżej budowy Portu Zewnętrznego w Gdyni, „Business Insider Polska” [online], 31 VII 2018 [dostęp: 6 IV 2019], dostępny w internecie: <https://businessinsider.com.pl/ wiadomosci/port-zewnetrzny-w-gdyni-umowa-na-inwentaryzacje-przyrodnicza/f161d46>.

17 TEU (ang. twenty-foot equivalent unit) - jednostka pojemności używana w odniesieniu do portów i statków, równoważna objętości kontenera o długości 20 stóp.

18 LNG (ang. liquefied natural gas) - naturalny gaz ziemny przygotowany do dystrybucji w procesie oczyszczenia z zanieczyszczeń i skraplania. 
Tabela 1. Obroty ladunkowe w Porcie Gdynia w latach 2014-2017 $z$ uwzględnieniem relacji (w tys. ton)

\begin{tabular}{|c|c|c|c|c|c|c|c|c|c|}
\hline \multirow{2}{*}{ Rok } & \multirow{2}{*}{ Ogólem } & \multirow{2}{*}{ Wyladunek } & \multirow{2}{*}{ Zaladunek } & \multicolumn{2}{|c|}{ Międzynarodowy obrót morski } & \multicolumn{3}{|c|}{ Krajowy obrót morski } \\
\cline { 5 - 10 } & & & & razem & wyladunek & zaladunek & razem & wyladunek & zaladunek \\
\hline 2014 & 16960,7 & 8479,6 & 8481,1 & 16833,9 & 8431,4 & 8402,4 & 126,8 & 48,2 & 78,7 \\
\hline 2015 & 15390,9 & 7751,4 & 7639,6 & 15284,3 & 7704,1 & 7580,3 & 106,6 & 47,3 & 59,3 \\
\hline 2016 & 17751,1 & 8855,4 & 8895,7 & 17398,5 & 8767,3 & 8631,1 & 352,6 & 88,1 & 264,6 \\
\hline 2017 & 18377,9 & 10378,9 & 7999,1 & 18219,3 & 10304,2 & 7915,1 & 158,6 & 74,6 & 84,0 \\
\hline
\end{tabular}

Źródło: „Rocznik Statystyczny Gospodarki Morskiej” = „Statistical Yearbook of Maritime Economy" 2018, s. 95

Jak wynika z tabeli 1, w 2017 r. przeładowano w Porcie Gdynia rekordowe 18,4 mln ton ładunków, głównie drobnicy skonteneryzowanej i ładunków masowych (węgla, zboża i paliw), dzięki czemu do budżetu państwa trafiło z Portu Gdynia ponad 6,5 mld zł (m.in. z podatków i ceł). Z kolei w pierwszym półroczu 2018 r. port przeładował 11,5 mln ton - o 11,3 proc. więcej niż w analogicznym okresie poprzedniego roku ${ }^{19}$.

ZMPG szacuje, że budowa Portu Zewnętrznego wygeneruje bezpośrednio ok. 300 miejsc pracy, a realizowane w przyszłości przeładunki przyczynią się do powstania nawet 7,5 tys. kolejnych (np. w spedycji). Z wykonanych analiz wynika, że Port Zewnętrzny mógłby zacząć funkcjonować już w 2024 r., realizując przeładunki ok. 250 tys. TEU, a do 2030 r. mogłyby one wzrosnąć do ok. 1,2 mln TEU. W związku z tym, że średnie przychody skarbu państwa uzyskiwane tytułem opłat celno-skarbowych (akcyzy, VAT-u i cła) z przeładowania jednego TEU wynoszą prawie 2,2 tys. zł, to gdyby we w pełni rozwiniętym Porcie Zewnętrznym dochodziło do przeładowywania założonych $2 \mathrm{mln}$ TEU, przychody skarbu państwa wyniosłyby $4,4 \mathrm{mld}$ zł.

Przy zestawieniu bieżących (wynikających z działalności Portu Gdynia opartej o obecnie istniejącą infrastrukturę) oraz perspektywicznych (uwzględniających funkcjonowanie planowanego Portu Zewnętrznego) obrotów ładunkowych przychody skarbu państwa przekroczyłyby $10 \mathrm{mld}$ zł. Zapisy Ustawy budżetowej na rok $2019^{20}$ zakładają dochody na poziomie $387,7 \mathrm{mld}$ zł (w tym 179,6 mld z VAT, 34,8 mld z CIT oraz 64,3 mld z PIT). Okazuje się, że tylko jeden podmiot gospodarczy - Port Gdynia - mógłby generować niemal 3 proc. tej kwoty.

19 Coraz blizej budowy...

20 Ustawa budżetowa na rok 2019, Dz.U. 2019, poz. 198. 


\section{Terminal elektrowni gazowej}

Znaczenie gazu ziemnego dla bezpieczeństwa energetycznego RP dobitnie potwierdzają statystyki i wyliczenia, które wskazują, że obecnie uśredniona wartość zużycia tego surowca w Polsce wynosi ok. 15 Mtoe rocznie, a dalsza perspektywa wskazuje dynamikę zwyżkową. Nawet przy założeniu bardzo intensywnego rozwijania energetyki opartej na odnawialnych źródłach energii i energii jądrowej zakłada się, że przy okresowej niedyspozycyjności źródeł słonecznych i wiatrowych to właśnie elektrownie gazowe będą przejmować ich rolęe

Plany inwestycyjne ZMPG zakładają co najmniej dwa etapy budowy Portu Zewnętrznego. W pierwszym (realizowanym do 2026 r.) założono wybudowanie:

- terminala kontenerowego,

- terminala pasażerskiego,

- terminala elektrowni gazowej,

- terminala LNG małej skali.

W etapie drugim (dla którego trudno oszacować czas ukończenia) przewidziano budowę:

- terminala kontenerowego o podobnych rozmiarach jak w etapie pierwszym,

- terminala uniwersalnego,

- terminala przeładunku paliw,

- terminala FSRU (ang. floating storage and regasification unit).

Na podstawie grafiki zaprezentowanej przez „Portal Morski” (ryc. 2) można stwierdzić, że rozmieszczenie terminali elektrowni gazowej i LNG małej skali zaplanowano we wschodniej części inwestycji oraz że będą się one znajdowały w bezpośrednim sąsiedztwie, co biorąc pod uwagę zarówno warunki bezpieczeństwa, jak i ergonomię oraz ekonomikę, wydaje się racjonalne.

Uwzględniając cel niniejszych rozważań, terminal elektrowni gazowej należy podzielić pod kątem funkcjonalnym ${ }^{22}$ na trzy zasadnicze części:

- elektrownię gazową, która zapewni założoną moc;

- pirs rozładunkowy, który zapewni miejsce postojowe dla jednostek transportujących LNG;

21 R. Miętkiewicz, Terminal FSRU Gdańsk jako element dywersyfikacji dostaw surowca o znaczeniu strategicznym, „Gospodarka Materiałowa i Logistyka” 2017, nr 12, s. 704-705.

22 Podział funkcjonalny pozwala określić przeznaczenie poszczególnych elementów terminala elektrowni gazowej oraz ich wzajemne relacje. 
- zbiorniki, które pozwolą na gromadzenie dostarczonego LNG i dalsze dystrybuowanie go do portowej elektrowni lub do innych odbiorców w głębi kraju.

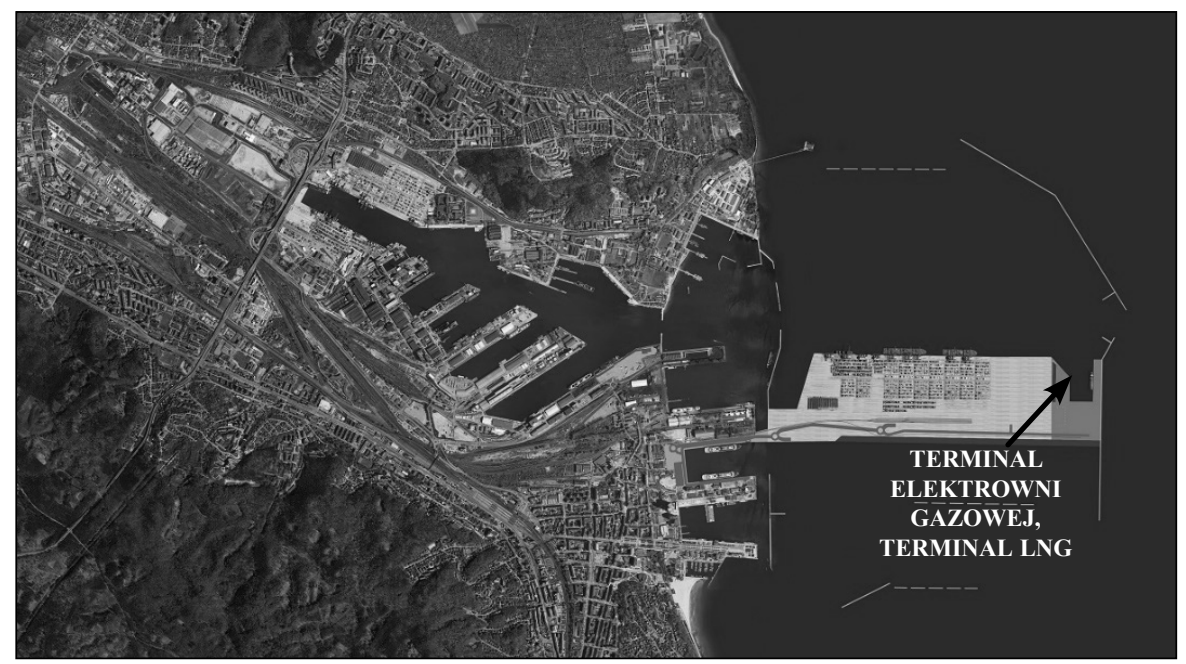

Ryc. 2. Port Gdynia i planowany Port Zewnętrzny ze wskazanymi terminalem elektrowni gazowej i terminalem LNG makej skali.

Źródło: Powstaje Port Zewnętrzny - umowa z Uniwersytetem Gdańskim, „Portal Morski” [online], 31 VII 2018 [dostęp: 12 IV 2019], dostępny w internecie: $<$ https://www.portalmorski.pl/porty-logistyka/ 40106-powstaje-port-zewnetrzny-umowa-z-uniwersytetem-gdanskim>

\section{Elektrownia gazowa}

Wszystkie planowane terminale Portu Zewnętrznego będą wymagały zasilania w energię elektryczną. Analizując jej konsumpcję w funkcjonujących już na świecie zespołach terminali o podobnej wielkości, można oszacować, że zapotrzebowanie Portu Zewnętrznego może wynosić nawet do $120 \mathrm{MW}$. W związku z powyższym koncepcja budowy terminala elektrowni gazowej (ryc. 3) mogącego pokryć część, a najlepiej całość zapotrzebowania energetycznego planowanego przedsięwzięcia (na prąd) oraz uniezależnić je w wariancie zasadniczym od dostaw zewnętrznych, wydaje się całkowicie uzasadniona. $\mathrm{W}$ ocenie autora $\mathrm{w}$ toku realizacji powyższego przedsięwzięcia administracja państwowa winna wymóc na inwestorze budowę elektrowni gazowej zapewniającej około pięćdziesięcioprocentową nadwyżkę energetyczną, która byłaby kierowana do ogólnokrajowej sieci energetycznej. Zaznacza 
się jednak, że przy uwzględnieniu wielkości Portu Zewnętrznego oraz rozmiarów elektrowni gazowych różnych mocy roszczenie budowy obiektu zapewniającego jeszcze większą nadwyżkę energetyczną miałoby istotny wpływ na ekonomikę ${ }^{23}$ całego przedsięwzięcia i ograniczyłoby jego zasadnicze przeznaczenie - transport ludzi i towarów drogą morską, które z punktu widzenia państwa jest równie istotne co bezpieczeństwo energetyczne.

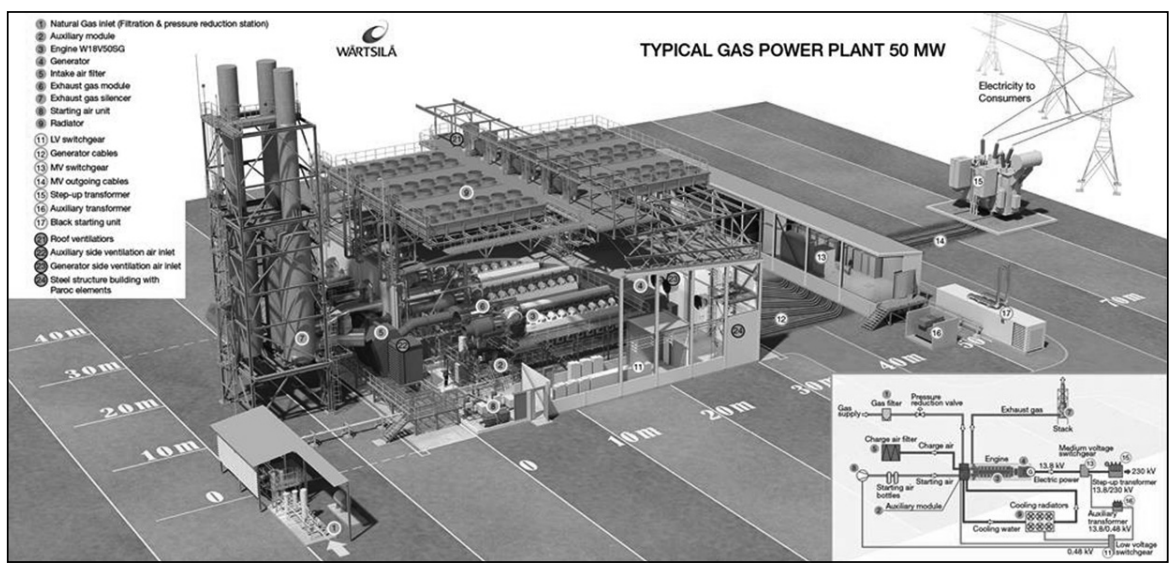

Ryc. 3. Przykładowa elektrownia gazowa o mocy 50 MW.

Źródło: Gas power plants, „Wärtsilä” [online, dostęp: 30 XI 2019], dostępny w internecie: $<$ https://www.wartsila.com/products/power-plants/solutions/gas-power-plants>

Z dużym prawdopodobieństwem można założyć, że jako podstawowe jednostki wytwórcze elektrowni wykorzystywane będą gazowe silniki tłokowe o zapłonie iskrowym, napędzające prądnice synchroniczne. Takie generatory prądotwórcze charakteryzują się zarówno wysoką sprawnością, jak i dużą elastycznością pracy (krótkim czasem uruchomienia i odstawienia, pracą z niskim obciążeniem i zdolnością do szybkich zmian mocy). Obecnie najpowszechniej stosowane są zespoły prądotwórcze o mocach 10, 12 i $18 \mathrm{MW}$, których połączenie w bloki pozwala uzyskać założoną moc elektrowni. Przykładowe zestawienia generujące zakładane 120 lub 180 MW zaprezentowano w tabeli 2.

23 W szacowaniu kosztu budowy elektrowni gazowej niezapewniającej odzysku ciepła można przyjąć przybliżoną zależność na poziomie 600 euro / $1 \mathrm{~kW}$. Uwzględniający te liczby koszt budowy elektrowni gazowej o mocy $120 \mathrm{MW}$ wyniesie ok. $72 \mathrm{mln}$ euro, a zapewniającej moc $180 \mathrm{MW}$ - ok. $108 \mathrm{mln}$ euro. 
Tabela 2. Przykładowe zestawienia generatorów prądotwórczych w planowanej elektrowni gazowej

\begin{tabular}{|c|c|c|}
\hline Zespoły / moc elektrowni & $\mathbf{1 2 0}$ MW & $\mathbf{1 8 0}$ MW \\
\hline Zespoły 10 MW & 2 bloki po 6 zespołów & 3 bloki po 6 zespołów \\
\hline Zespoły 12 MW & 2 bloki po 5 zespołów & 3 bloki po 5 zespołów \\
\hline Zespoły 18 MW & 2 bloki - po 3 i 4 zespoły* & 2 bloki po 5 zespołów \\
\hline * Zostaje nadwyżka 6 MW.
\end{tabular}

Źródło: oprac. własne

\section{Pirs rozładunkowy}

Uwzględniając ogólne wymiary planowanej inwestycji Portu Zewnętrznego oraz zakładane przez ZMPG proporcje ${ }^{24}$ pomiędzy jej poszczególnymi terminalami, a także treści z ryciny 2 , można konstatować, że na potrzeby elektrowni gazowej wybudowany zostanie pirs o łącznej długości ok. $400 \mathrm{~m}$, składający się z dwóch oddzielnych miejsc postojowych o długościach ok. $200 \mathrm{~m}$, wybudowanych pod kątem. Takie warunki manewrowania i postoju pozwolą na jednoczesny bezpieczny rozładunek dwóch małych zbiornikowców LNG (np. bunkierek ${ }^{25}$ ). Przykładem tego rodzaju nowoczesnej jednostki jest zwodowany 18 maja 2018 r. m/v Kairos ${ }^{26}$ (ryc. 4), który wyposażono w dwa zbiorniki o łącznej pojemności $7500 \mathrm{~m}^{3}$ i dwie pompy o łącznej wydajności do $1250 \mathrm{~m}^{3} / \mathrm{h}$. Kairos wybudowany został w stoczni Hyundai Mipo Dockyard w południowokoreańskim mieście Ulsan i obecnie wykorzystywany jest w litewskim terminalu Klaipedos Nafta w Kłajpedzie ${ }^{27}$.

Pirs rozładunkowy powinien zostać wyposażony w ramiona przeładunkowe umożliwiające połączenie rurociągów gazowca i terminala, instalację gaśniczą,

24 Zasadniczą częścią zamierzeń inwestycyjnych jest terminal kontenerowy.

25 Bunkierka LNG - wyposażony we własne urządzenia do przeładunku niewielki zbiornikowiec lub barka do zaopatrywania statków (okrętów) i instalacji brzegowych w LNG, który realizuje swoje zadania w portach, na redach oraz pełnym morzu.

26 Charakterystyka zbiornikowca bunkrowego LNG Kairos: długość całkowita - 117,07 m, szerokość całkowita - 20,05 m, zanurzenie - 5,212 m, wysokość od stępki do szczytu najwyższego masztu - 36,62 m, wyporność - 9026 t, pojemność ładunkowa $-7521 \mathrm{~m}^{3}$, moc napędu głównego - MCR 1665 kW (2264 KM), prędkość eksploatacyjna - 12,5 węzła, załoga - 14 osób.

27 Kairos - największa bunkierka LNG świata pracuje na Morzu Battyckim, „Portal Stoczniowy" [online], 14 XII 2018 [dostęp: 16 IV 2019], dostępny w internecie: $<$ https://portalstoczniowy.pl/wiadomosci/kairos-najwieksza-bunkierka-lng-swiatapracuje-na-morzu-baltyckim/>; Największa $w$ świecie bunkierka LNG rozpoczyna prace na Battyku, „Portal Morski” [online], 12 XII 2018 [dostęp: 16 IV 2019], dostępny w internecie: <https://www.portalmorski.pl/stocznie-statki/41260-najwiekszadotad-bunkierka-lng-rozpoczyna-prace-na-baltyku>. 
a także system rurociągów przesyłowych odpowiadających za transfer gazu do naziemnych lub podziemnych zbiorników kriogenicznych (chłodzonych) ${ }^{28}$.

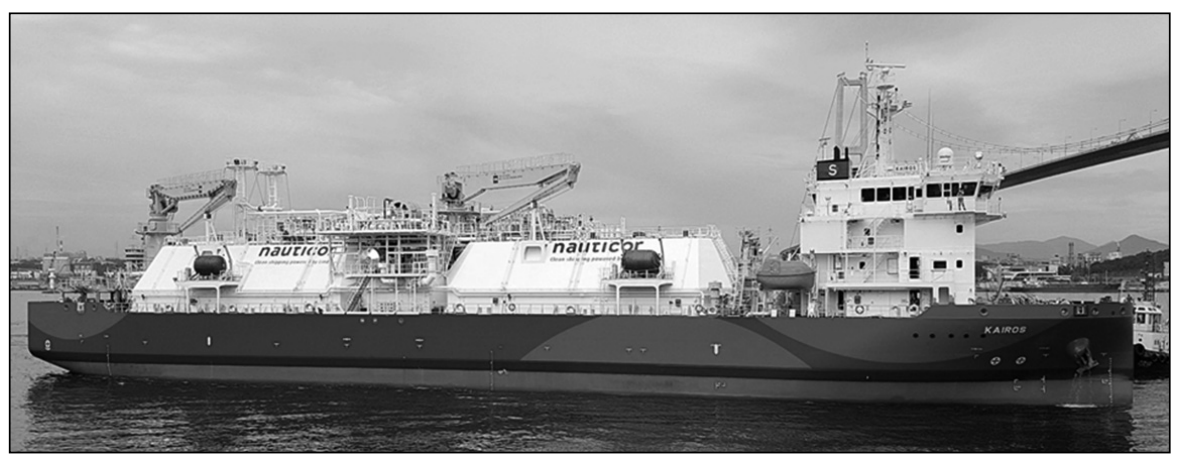

Ryc. 4. Kairos - jednostka klasy GSV (ang. gas supply vessel).

Źródło: Kairos - największa bunkierka...

\section{Zbiorniki}

Biorąc pod uwagę ogólne uwarunkowania tego fragmentu inwestycji, można założyć, że na potrzeby pracy terminala elektrowni gazowej zostaną wybudowane zbiorniki zdolne pomieścić ok. $50000 \mathrm{~m}^{3}$ LNG. Jego przeciętny skład procentowy obejmuje: $91-92$ proc. metanu, $6-7,2$ proc. propanu oraz maksimum 2 proc. wszelkich frakcji węglowodorowych. Regazyfikacja $1 \mathrm{~m}^{3} \mathrm{LNG}$ pozwala uzyskać do $600 \mathrm{~m}^{3}$ gazu. Podczas skraplania jego objętość redukuje się aż 630-krotnie. LNG jest bezwonny, bezbarwny, nietoksyczny i nie powoduje korozji. Ze względu na zróżnicowany skład chemiczny oraz zmienną zawartość metanu gęstość surowca waha się w przedziale $420-510 \mathrm{~kg} / \mathrm{m}^{329}$. W lądowych sieciach prowadzących do systemów i urządzeń odbiorczych gaz ziemny transportuje się rurociągami w postaci skompresowanej CNG (ang. compressed natural gas - sprężony gaz ziemny). W terminalu elektrowni gazowej musi zatem zostać przeprowadzony proces regazyfikacji, tj. zamiany cieczy przewożonej przez zbiornikowiec i przechowywanej w zbiornikach na sprężony gaz poprzez podgrzanie cieczy powyżej temperatury krytycznej ${ }^{30}$, co zgodnie z przyjętą koncepcją realizacyjną następować będzie w samej elektrowni gazowej.

28 B. Pączek, Rola transportu morskiego gazu skroplonego w Systemie Bezpieczeństwa Energetycznego Polski, „Logistyka” 2012, nr 2, s. 795.

29 R. Miętkiewicz, Terminal..., s. 704.

30 J. Herdzik, Możliwości przeładunku skroplonego gazu naturalnego LNG z gazowca zakotwiczonego na redzie, „Logistyka” 2015, nr 3, s. 1784. 
Wobec powyższego w celu zwiększenia możliwości dostaw gazu ziemnego do Polski drogą morską w obszarze lądowym (nabrzeża) terminala elektrowni gazowej powinny zostać rozmieszczone:

- instalacja do regazyfikacji (odparowywania) skroplonego gazu wraz ze stacją pomp tłoczących do przyłącza krajowego systemu sieciowego,

- instalacja pakietyzacyjna, służąca napełnianiu zbiorników i kontenerów gazowych LNG (ryc. 5) w celu dalszego transportowania paliwa w głąb kraju siecią kolejową lub drogową.

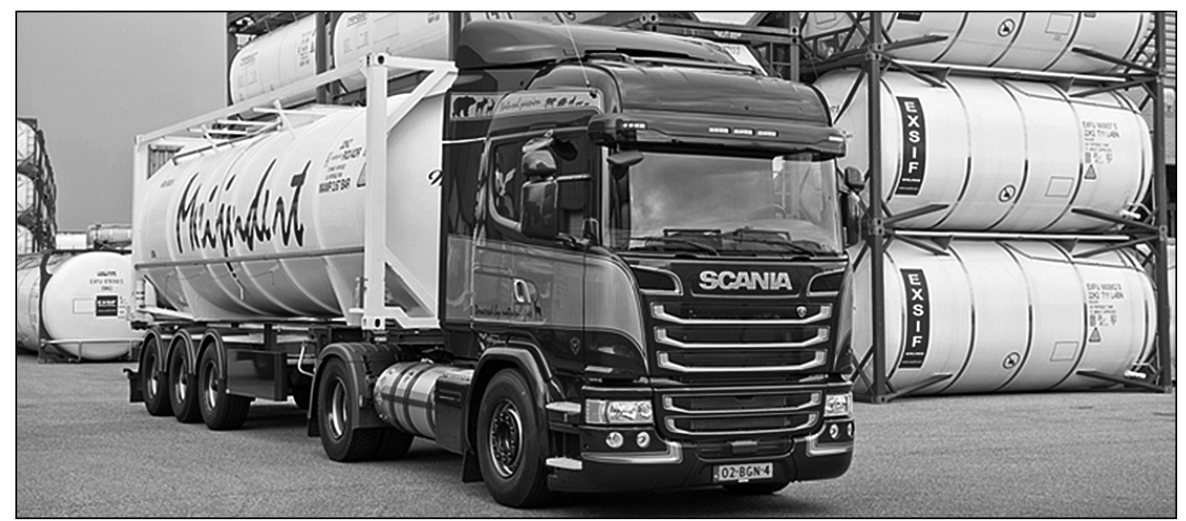

Ryc. 5. Ciągnik siodłowy z naczepą transportujący kontener gazowy LNG.

Źródło: Pierwszy w Europie ciagnik siodlowy na LNG w petni zgodny z ADR, czyli Scania G340 na gaz ziemny, „40 Ton” [online], 1 XII 2015 [dostęp: 19 IV 2019], dostępny w internecie: <https://40ton.net/pierwszy-w-europie-ciagnik-siodlowy-na-lng-w-pelnizgodny-z-adr-czyli-scania-g340-na-gaz-ziemny/>

\section{Podsumowanie}

Nie posiadając wystarczających i zróżnicowanych własnych źródeł surowców energetycznych, Polska należy do państw zależnych od zewnętrznych dostaw gazu ziemnego i ropy naftowej, realizowanych m.in. drogą morską. Utrzymanie bieżącej dynamiki wzrostu gospodarczego oraz postępujący rozwój technologiczny kraju uzależnione są bezpośrednio od możliwości produkcji energii elektrycznej. Procesy te nie mogą mieć negatywnego wpływu na środowisko naturalne, co wymusza zmniejszanie udziału węgla na rzecz gazu ziemnego. Ponadto postępująca dywersyfikacja źródeł i kierunków dostaw surowców energetycznych znacząco wpływa na możliwości i postawy negocjacyjne wobec perspektywicznych umów.

Realizacja zamierzeń inwestycyjnych ZMPG, wyrażonych w koncepcji budowy Portu Zewnętrznego w Gdyni, sprowadza się do wybudowania dwóch 
terminali kontenerowych, terminala pasażerskiego, terminala elektrowni gazowej, terminala LNG małej skali, terminala uniwersalnego, terminala przeładunku paliw oraz terminala FSRU, przyczyniających się do rozwoju nie tylko miasta, ale również kraju.

Na podstawie przeprowadzonej analizy konsumpcji energii elektrycznej przez zespoły terminali porównywalne do planowanego Portu Zewnętrznego oraz możliwości produkcyjnych elektrowni gazowych dedykowanych infrastrukturze portowej stwierdzono, że możliwe jest uzyskanie ok. 50 proc. nadwyżki, która winna zostać skierowana do ogólnokrajowej sieci energetycznej.

Ponadto na przykładzie zaprezentowanego wcześniej małego zbiornikowca Kairos można oszacować, że łączny czas pełnego rozładunku $7500 \mathrm{~m}^{3}$ LNG (zacumowania, podłączenia, rozładowania, rozłączenia i odcumowania) wynosi około ośmiu godzin, co odpowiada jednej zmianie w trybie pracy. W związku z tym, że planowany terminal elektrowni gazowej będzie dysponował pirsem rozładunkowym pozwalającym na jednoczesną obsługę dwóch takich jednostek, możliwe będzie przyjęcie $15000 \mathrm{~m}^{3} \mathrm{LNG}$ w ciągu ośmiu godzin.

Zasilenie elektrowni gazowej o mocy $120 \mathrm{MW}$ (wariant pozwalający na zabezpieczenie energetyczne potrzeb Portu Zewnętrznego) wymaga dostarczenia ok. $45 \mathrm{~m}^{3} \mathrm{LNG}$ na godzinę. Pełne wykorzystanie możliwości drugiego $\mathrm{z}$ analizowanych wariantów (zasilania Portu Zewnętrznego oraz kierowania nadwyżki do krajowej sieci energetycznej), tj. elektrowni gazowej o mocy $180 \mathrm{MW}$, zwiększa konsumpcję LNG do ok. $60 \mathrm{~m}^{3} / \mathrm{h}$. Oznacza to dobowe zapotrzebowanie nieprzekraczające odpowiednio 1100 i $1500 \mathrm{~m}^{3} \mathrm{LNG}$.

Przy założeniu, że dokonany zostanie wybór elektrowni gazowej o mocy 180 MW, zapewniającej jednoczesne zasilanie Portu Zewnętrznego oraz przekazywanie 60 MW mocy energii elektrycznej do krajowej sieci energetycznej, okazuje się, że jeden rozładunek dwóch zbiornikowców typu Kairos pozwala zapewnić nieprzerwaną pracę elektrowni przez dziesięć dób.

Możliwości rozpatrywanych zbiorników i pirsu rozładunkowego, wchodzących w skład struktury terminala elektrowni gazowej, zdecydowanie przewyższają przewidziany powyżej wariant. Wobec tego każde zwiększenie rozładunków pozwoli na dostarczanie uzyskanych w ten sposób nadwyżek LNG do innych podmiotów sektora energetycznego kraju. Dla scenariusza zakładającego comiesięczny rozładunek dwunastu zbiornikowców typu Kairos przy założeniu gęstości LNG na poziomie $500 \mathrm{~kg} / \mathrm{m}^{3}$ daje się oszacować, że przy jednoczesnej pracy elektrowni gazowej o mocy $180 \mathrm{MW}$ możliwe będzie jednoczesne (w tym samym okresie miesięcznym) wysłanie 
do odbiorców ok. 1400 kriogenicznych kontenerów zbiornikowych ${ }^{31}$ o długości czterdziestu stóp.

Biorąc pod uwagę fakt, że zasadniczą funkcją planowanego terminala elektrowni gazowej ma być zasilanie w energię elektryczną Portu Zewnętrznego, przy uwzględnieniu założeń i idei towarzyszących niniejszym badaniom, ukierunkowanym na zwiększenie możliwości dostaw gazu ziemnego drogą morską oraz dodatkową produkcję energii elektrycznej, można konstatować, że zgodnie z dokonanymi obliczeniami przedsięwzięcie to przyczyni się do zwiększenia bezpieczeństwa energetycznego RP.

Wyniki przedstawionych badań wskazują na osiągnięcie celu głównego oraz rozwiązanie problemu głównego niniejszego opracowania. W ramach przywoływanej na wstępie pracy badawczej odnośnie do planów budowy Portu Zewnętrznego w Gdyni analizowane są aktualnie terminal LNG małej skali i terminal FSRU. Niezależnie od tego w Akademii Marynarki Wojennej planowane są odrębne badania dotyczące integracji portu z zapleczem gospodarczym kraju poprzez wydajną infrastrukturę kolejową i drogową oraz analiza zbieżności zamierzeń inwestycyjnych ZMPG z obowiązującymi politykami i strategiami (Polityka energetyczna Unii Europejskiej do 2030 r., Polityka energetyczna Polski do 2030 r., Zintegrowana polityka morska Unii Europejskiej, Polityka morska Rzeczypospolitej Polskiej do 2020 r. z perspektywą do 2030 czy Strategiczna koncepcja bezpieczeństwa morskiego Rzeczypospolitej Polskiej).

\section{Bibliografia}

Apanowicz J., Metodologia ogólna, Bernardinum, Gdynia 2002.

Coraz bliżej budowy Portu Zewnętrznego w Gdyni, „Business Insider Polska” [online], 31 VII 2018

[dostęp: 6 IV 2019], dostępny w internecie: <https://businessinsider.com.pl/wiadomosci/ port-zewnetrzny-w-gdyni-umowa-na-inwentaryzacje-przyrodnicza/f161d46>.

Duda A., Stowo wstępne, [w:] Strategiczna koncepcja bezpieczeństwa morskiego Rzeczypospolitej Polskiej, Biuro Bezpieczeństwa Narodowego, Warszawa-Gdynia 2017.

Energia 2018 = Energy 2018, Główny Urząd Statystyczny, Warszawa 2018.

Ficoń K., Logistyka morska - statki, porty, spedycja, BEL Studio, Warszawa 2010.

Forum Gospodarki Morskiej Gdynia 2017, „Centrum Prasowe PAP” [online], 21 VI 2017 [dostęp: 15 III 2019], dostępny w internecie: <http://centrumprasowe.pap.pl/cp/pl/news/ info/100567,1,forum-gospodarki-morskiej-gdynia-2017>.

Gas power plants, „Wärtsilä” [online, dostęp: 30 XI 2019], dostępny w internecie: <https:// www.wartsila.com/products/power-plants/solutions/gas-power-plants>.

Global carbon budget 2017, Copernicus Publications, 2018.

31 Kriogeniczny kontener zbiornikowy o długości czterdziestu stóp wykonany zgodnie ze standardem ISO (ISO-kontener) zdolny jest pomieścić ok. 16 t LNG. 
Terminal elektrowni gazowej ujęty w koncepcji budowy Portu Zewnętrznego w Gdyni...

Gospodarka paliwowo-energetyczna w latach 2016 i $2017=$ Energy statistics in 2016 and 2017, Główny Urząd Statystyczny, Warszawa 2018.

Herdzik J., Możliwości przeładunku skroplonego gazu naturalnego LNG z gazowca zakotwiczonego na redzie, „Logistyka” 2015, nr 3.

Kairos - największa bunkierka LNG świata pracuje na Morzu Battyckim, „Portal Stoczniowy” [online], 14 XII 2018 [dostęp: 16 IV 2019], dostępny w internecie: $<$ https://portalstoczniowy. pl/wiadomosci/kairos-najwieksza-bunkierka-lng-swiata-pracuje-na-morzu-baltyckim/>.

Miętkiewicz R., Terminal FSRU Gdańsk jako element dywersyfikacji dostaw surowca o znaczeniu strategicznym, „Gospodarka Materiałowa i Logistyka” 2017, nr 12.

Największa w świecie bunkierka LNG rozpoczyna pracę na Bałtyku, „Portal Morski” [online], 12 XII 2018 [dostęp: 16 IV 2019], dostępny w internecie: <https://www.portalmorski.pl/ stocznie-statki/41260-najwieksza-dotad-bunkierka-lng-rozpoczyna-prace-na-baltyku>.

Pączek B., Rola transportu morskiego gazu skroplonego w Systemie Bezpieczeństwa Energetycznego Polski, „Logistyka” 2012, nr 2.

Pierwszy w Europie ciagnik siodtowy na LNG w petni zgodny z ADR, czyli Scania G340 na gaz ziemny, „40 Ton” [online], 1 XII 2015 [dostęp: 19 IV 2019], dostępny w internecie: $<$ https://40ton.net/pierwszy-w-europie-ciagnik-siodlowy-na-lng-w-pelni-zgodny-zadr-czyli-scania-g340-na-gaz-ziemny/>.

Port Zewnętrzny, Port Gdynia, Gdynia 2019, dostępny w internecie [dostęp: 20 XI 2019]: <https:// oficynamorska.pl/wp-content/uploads/2018/10/Konf.-prasowa-2018-10-17m.pdf>.

Port Zewnętrzny na Forum Gospodarki Morskiej, „Gospodarka Morska” [online], 12 X 2017 [dostęp: 18 III 2019], dostępny w internecie: <https://www.gospodarkamorska.pl/ Porty,Transport/port-zewnetrzny-na-forum-gospodarki-morskiej.html>.

Powstaje Port Zewnętrzny - umowa z Uniwersytetem Gdańskim, „Portal Morski” [online], 31 VII 2018 [dostęp: 12 IV 2019], dostępny w internecie: <https://www.portalmorski.pl/ porty-logistyka/40106-powstaje-port-zewnetrzny-umowa-z-uniwersytetem-gdanskim>.

Pracowity rok 2018 Portu Gdynia. Cel główny-Port Zewnętrzny, „Port Gdynia” [online], 13 XII 2018 [dostęp: 26 III 2019], dostępny w internecie: <https://www.port.gdynia.pl/pl/wydarzenia/aktualnosci/1305-pracowity-rok-2018-portu-gdynia-cel-glowny-port-zewnetrzny>.

„Rocznik Statystyczny Gospodarki Morskiej” = „Statistical Yearbook of Maritime Economy” 2018.

Rydzkowski W., Wojewódzka-Król K., Transport. Aktualne problemy integracji z UE, Wydawnictwo Naukowe PWN, Warszawa 2008.

Strategiczna koncepcja bezpieczeństwa morskiego Rzeczypospolitej Polskiej, Biuro Bezpieczeństwa Narodowego, Warszawa-Gdynia 2017.

Szadurski S., Budowa Portu Zewnętrznego w Gdyni. Trwaja poszukiwania inwestora, który pomoże sfinansować przedsięwzięcie, „Dziennik Bałtycki” [online], 18 X 2018 [dostęp: 24 III 2019], dostępny w internecie: $<$ https://dziennikbaltycki.pl/budowa-portu-zewnetrznego-w-gdyni-trwaja-poszukiwania-inwestora-ktory-pomoze-sfinansowac-przedsiewzie cie-zdjecia-wizualizacja/ar/13597584>.

Ustawa budżetowa na rok 2019, Dz.U. 2019, poz. 198. 